\title{
Peran Bpk Sebagai Lembaga Pengawas Eksternal Pengelolaan Keuangan Negara
}

\author{
Nawang Xalma Kaldera, Muthi Aulia, Hani Adila Faza \\ email : Nawang17001@mail.unpad.ac.id, Muthi17001@mail.unpad.ac.id, Hani17002@mail.unpad.ac.id
}

Fakultas Hukum, Universitas Padjadjaran, Bandung

\begin{abstract}
The establishment of Badan Pemeriksa Keuangan (BPK) as an independent supervisory body aimed to create a clean and corruption free government. This writing aims to explain the role and function of BPK towards state finances, and the source of its competence. The author uses normative juridical research methods with literature studies. The results showed that BPK is a repressive and external supervisory body, and also played major role in detecting and minimalizing all weaknesses in the management of state finances. The establishment of BPK as supervisory body whose source of authority is coming from the mandate of UUD 1945 is also to evaluate the management of state finances and reduce state financial losses.
\end{abstract}

\section{Keywords: Badan Pemeriksa Keuangan, State Finances}

Salah satu upaya untuk mewujudkan pemerintahan yang bersih dan bebas dari korupsi, kolusi, dan nepotisme (KKN) adalah dengan dibentuknya Badan Pemeriksa Keuangan sebagai lembaga pengawas yang independen. Artikel ini bertujuan untuk menjelaskan peran dan fungsi BPK terhadap keuangan negara, serta sumber dari kewenangan yang dimilikinya. Penulis menggunakan metode penelitian yuridis normatif dengan studi kepustakaan. Hasil penelitian menunjukkan bahwa BPK melakukan fungsi pengawasannya secara represif dan eksternal, serta berperan besar dalam mendeteksi dan meminimalisir segala kelemahan yang terdapat dalam pengelolaan keuangan negara. BPK sebagai lembaga pengawas yang sumber kewenangannya berasal dari amanat UUD 1945 berfungsi untuk mengevaluasi pengelolaan keuangan negara dan mengurangi kerugian keuangan negara.

Kata kunci: Badan Pemeriksa Keuangan, Keuangan Negara.

\section{PENDAHULUAN}

Untuk dapat mewujudkan penyelenggaraan negara yang bersih dan terhindar dari praktik korupsi, kolusi, dan nepotisme (KKN), diperlukan adanya peran dari suatu lembaga negara yang dapat memeriksa kinerja sistem pengelolaan keuangan negara dalam sistem ketatanegaraan Indonesia. Pengelolaan Keuangan Negara itu sendiri merupakan keseluruhan kegiatan pejabat pengelola keuangan negara sesuai dengan kedudukan dan kewenangannya, yang meliputi perencanaan, pelaksanaan, pengawasan, dan pertanggungjawaban. ${ }^{[1]}$ Upaya pemerintah untuk mewujudkan hal tersebut adalah membentuk suatu badan pengawas terhadap pengelolaan keuangan negara. Pasal 23 ayat (5) UUD Tahun 1945 sebelum amandemen menetapkan bahwa dalam memeriksa tanggung jawab mengenai Keuangan Negara, maka diadakan suatu Badan 
Pemeriksa Keuangan (BPK) yang peraturannya ditetapkan dalam Undang-undang, yang kemudian hasil pemeriksaan tersebut disampaikan kepada Dewan Perwakilan Rakyat Republik Indonesia (DPR RI). ${ }^{[2]}$

Kemudian mulai muncul keinginan untuk menyempurnakan BPK agar dapat menjadi alat kontrol yang efektif sebagaimana tercantum di dalam amanat-amanat Presiden, yaitu Deklarasi Ekonomi dan Ambeg Parama Arta, dan di dalam Ketetapan MPRS No. 11/MPRS/1960, serta resolusi MPRS No. 1/Res/MPRS/1963. Dalam rangka mencapai tujuan tersebut maka pada tanggal 12 Oktober 1963, Pemerintah mengeluarkan Peraturan Pemerintah Pengganti Undangundang No. 7 Tahun 1963 (LN No. 195 Tahun 1963) yang kemudian diganti dengan UndangUndang (PERPU) No. 6 Tahun 1964 tentang Badan Pemeriksa Keuangan Gaya Baru. Pada era reformasi, BPK mendapat dukungan konstitusi dari MPR RI dalam Sidang Tahun 2002 yang memperkuat kedudukan BPK sebagai lembaga pemeriksa eksternal di bidang Keuangan Negara. Dengan dikeluarkannya TAP MPR Nomor VI/MPR/2002, kedudukan BPK ditegaskan kembali sebagai satu-satunya lembaga pemeriksa eksternal keuangan negara dan yang peranannya bersifat independen dan profesional. ${ }^{[3]} \mathrm{Hal}$ ini didukung dengan tercantumnya ketentuan yang mengatur tentang tugas dan wewenang BPK dalam konstitusi tersebut.

Berdasarkan uraian di atas, penulis kemudian formulasikan dalam bentuk identifikasi masalah, yaitu : a) bagaimana batasan dan darimana sumber kewenangan yang dimiliki BPK dalam melakukan pengawasan terhadap pengelolaan keuangan negara?; b) bagaimana mekanisme pengawasan yang dilakukan oleh BPK terhadap pengelolaan keuangan negara?; dan c) bagaimana tindak lanjut dari hasil pengawasan oleh BPK terhadap pengelolaan keuangan negara?

\section{METODE PENELITIAN}

Metode pendekatan ini menggunakan metode pendekatan Yuridis Normatif, yaitu suatu pendekatan masalah dengan jalan menelaah dan mengkaji peraturan perundang-undangan yang berlaku dan berkompeten untuk digunakan sebagai dasar dalam melaksanakan pemecahan masalah. Pemecahan masalah yang dimaksudkan adalah mengungkapkan berbagai aturan atau norma-norma yang dapat digunakan untuk menentukan peran penting BPK dalam melakukan pengawasan terhadap pengelolaan keuangan negara menurut sistem hukum yang berlaku di Indonesia. Spesifikasi penelitian ini adalah Deskriptif Analitis, yaitu penelitian yang sifat dan tujuannya memberikan deskripsi atau menggambarkan mekanisme pemeriksaan oleh BPK dalam melakukan pengawasan terhadap pengelolaan keuangan negara menurut sistem hukum yang berlaku di Indonesia. Data yang akan digunakan dalam penelitian ini data sekunder, yaitu data yang diperoleh dengan melakukan studi dokumen yang terdiri dari peraturan perundangundangan, kajian dan jurnal ilmiah, buku-buku, dan artikel berita. Analisis yang dipilih dalam penelitian ini adalah analisis kualitatif yang tidak hanya mampu memperoleh kesimpulan semata, tetapi juga mampu dipergunakan untuk pengembangan suatu penelitian baru yang sejenis.

\footnotetext{
2 BPK RI, “Sejarah BPK RI”, diakses melalui https://www.bpk.go.id/menu/sejarah, pada 28 Maret 2020 Ibid
} 
Pada dasarnya, segala upaya untuk menyempurnakan keberadaan BPK ditujukan untuk memperkuat BPK sebagai lembaga independen agar dapat menjalankan fungsinya dengan maksimal. Sumber dari kewenangan yang dimiliki oleh BPK itu sendiri berasal dari falsafah pembentukannya dimana negara membutuhkan suatu lembaga yang kuat dan dapat dipercaya untuk mengawasi pengelolaan keuanga negara. Dasar kewenangan penilaian oleh BPK diatur lebih lanjut dalam Undang-Undang Republik Indonesia Nomor 15 Tahun 2006 Tentang Badan Pemeriksa Keuangan (UU No. 15 Tahun 2006 BPK). ${ }^{[4]}$ Selain itu, tujuan dari eksistensi BPK tercantum dalam pembukaan UU No. 15 Tahun 2006 BPK yaitu untuk mencapai tujuan negara dalam mewujudkan masyarakat yang adil, makmur dan sejahtera sebagaimana diamanatkan dalam Pembukaan UUD 1945, pengelolaan dan tanggung jawab keuangan negara memerlukan suatu lembaga pemeriksa yang bebas, mandiri, dan profesional untuk menciptakan pemerintahan yang bersih dan bebas dari korupsi, kolusi, dan nepotisme $(\mathrm{KKN})^{[5]}$.

Berdasarkan kewenangan yang dimiliki BPK dalam melakukan pengawasan serta dilihat dari mekanisme pemeriksaannya. Bentuk pengawasan yang dilakukan BPK ini adalah pengawasan Represif, yaitu pemeriksaan dilakukan setelah pekerjaan dilaksanakan untuk menentukan apakah pengelolaan dilakukan sesuai dengan prosedur atau tidak, telah efisien atau tidak dan apakah tujuan dari pekerjaan yang dilakukan telah tercapai atau belum, dan dilakukan oleh lembaga Eksternal yang bukan merupakan bagian dari lembaga yang diperiksanya. Pemeriksaan yang dilakukan oleh BPK menghasilkan produk berupa Hasil Pemeriksaan dan Opini BPK yang kemudian dilaporkan kepada lembaga yang bersangkutan untuk ditindak lebih lanjut, dimana dalam hal ini BPK berfungsi sebagai pendeteksi kelemahan, termasuk kelalaian dan kejahatan dalam sistem pengelolaan keuangan negara. BPK juga menjadi lembaga yang berperan untuk mendorong kesadaran seluruh penyelenggara negara supaya memiliki integritas dalam mengelola Keuangan Negara.

\section{A. Sumber dan Batasan Kewenangan BPK dalam Melakukan Pengawasan terhadap Pengelolaan Keuangan Negara}

Pasal 23 Ayat (5) UUD 1945 sebelum amandemen menyebutkan bahwa pemeriksaan tanggung jawab terhadap keuangan ngeara dilakukan oleh suatu Badan Pemeriksa Keuangan yang peraturannya ditetapkan dengan undang-undang. Melalui ayat tersebut, terlihat bahwa perumus UUD 1945 sebelum amandemen menyadari bahwa pemeriksaan pengelolaan serta tanggung jawab pemerintah terhadap keuangan negara merupakan kewajiban yang berat, sehingga diperlukan suatu badan yang independen agar terlepas dari pengaruh maupun kekuasaan pemerintah. ${ }^{[6]}$ Pembentukan BPK ini merupakan suatu alat penengah, mengingat perwakilan rakyat yang terus menerus tidak percaya dengan pemerintah. Hal ini lah yang kemudian mendasari pembentukan

\footnotetext{
4 Muhammad Imron Rosyadi, "Wewenang Badan Pemeriksa Keuangan dan Badan Pengawasan Keuangan dan Pembangunan Dalam Menilai Kerugian Keuangan Negara”, Mimbar Keadilan, Jurnal Ilmu Hukum, Januari-Juni 2016, hal. 40

5 Undang-Undang Nomor 15 Tahun 2006 tentang Badan Pemeriksa Keuangan

6 Muhammad Imron Rosyadi, Op. Cit, hal. 26.
} 
lembaga penengah yang tidak berada dibawah lembaga manapun dan dihararpkan dapat menjadi pihak ketiga yang netral. ${ }^{[7]}$ Setelah amandemen, UUD 1945 memiliki tempat tersendiri bagi pengaturan mengenai kelembagaan BPK yaitu pada BAB VIII A Badan Pemeriksa Keuangan yang terdiri dari Pasal 23 E, Pasal 23 F dan Pasal 23 G. Sejak 2003 ada empat Undang-Undang yang dijadikan landasan operasonal BPK: UU No. 17 Tahun 2003 tentang Keuangan Negara; UU No. 15 Tahun 2004 tentang Pemeriksaan Pengelolaan dan Tanggung Jawab Keuangan Negara; UU No. 1 Tahun 2004 tentang Perbendaharaan; serta UU No. 15 Tahun 2006 tentang BPK.

Apabila dikaitkan dengan konsepsi Good Governance atau Pemerintahan yang Baik, lahirnya kewenangan BPK dapat ditinjau melalui kenyataan apakah pemerintah telah melakukan pemerintahan yang solid dan bertanggung jawab, serta efisien dan efektif dalam melakukan pengawasannya. Sebagaimana diatur dalam BAB VIII A BPK UUD 1945, dimana tujuan dari pembentukkan BPK adalah sebagai pengawas terhadap pengelolaan keuangan yang dilakukan pemerintah, BPK memiliki fungsi untuk mengamankan keuangan negara dan pemakaian yang tidak semestinya. Oleh karena itu, BPK memiliki fungsi sebagai penjaga harta negara. ${ }^{[8]}$ Selain pembentukan BPK tersebut, perlu dikaji pula kesesuaian kewenangan yang dimiliki oleh BPK tersebut dengan amanat UUD 1945 dan apakah lembaga tersebut telah menjalankan pengawasannya secara efektif, efisien dan sesuai dengan tujuan pembentukannya.

BPK sebagai penjaga harta negara memiliki tugas yang dituangkan dalam Pasal 6 Ayat (1) UU No. 15 Tahun 2006 tentang BPK yang menjelaskan bahwa "BPK bertugas memeriksa pengelolaan dan tanggung jawab keuangan negara yang dilakukan oleh Pemerintah Pusat, Pemerintah Daerah, Lembaga Negara lainnya, Bank Indonesia, Badan Usaha Milik Negara, Badan Layanan Umum, Badan Usaha Milik Daerah, dan lembaga atau badan lain yang mengelola keuangan negara."[9]

BPK memiliki kewenangan yang diatur berdasarkan Pasal 9 Ayat (1) UU No. 15 Tahun 2006 $\mathrm{BPK}:{ }^{[10]}$

"Dalam melaksanakan tugasnya, BPK berwenang untuk:

a. BPK memiliki wewenang untuk menentukan objek pemeriksaan, merencanakan serta melaksanakan pemeriksaan. Penentuan waktu dan metode pemeriksaan serta menyusun maupun menyajikan laporan juga menjadi wewenang dari BPK tersebut.

b. meminta keterangan dan/atau dokumen yang wajib diberikan oleh setiap orang, unit organisasi Pemerintah Pusat, Pemerintah Daerah, Lembaga Negara lainnya, Bank Indonesia, Badan Usaha Milik Negara, Badan Layanan Umum, Badan Usaha Milik Daerah, dan lembaga atau badan lain yang mengelola keuangan negara;

c. melakukan pemeriksaan di tempat penyimpanan uang dan barang milik negara, di tempat pelaksanaan kegiatan, pembukuan dan tata usaha keuangan negara, serta pemeriksaan terhadap perhitungan-perhitungan, surat-surat, bukti-bukti, rekening koran, pertanggungjawaban, dan daftar lainnya yang berkaitan dengan pengelolaan keuangan negara;

d. menetapkan jenis dokumen, data, serta informasi mengenai pengelolaan dan tanggung jawab

\footnotetext{
${ }^{7}$ Hendar Ristriawan, "Pengawasan Keuangan Negara dan Pemeriksaan Keuangan Negara" disampaikan dalam Kuliah Umum Fakultas Hukum Universitas Padjadjaran, pada 21 Mei 2020.

8 BPK RI, "BPK Mempunyai Tugas dan Fungsi Sebagai Penjaga Harta Negara", diakses melalui https://www.bpk.go.id/ news/bpk-mempunyai-tugas-dan-fungsi-sebagai-penjaga-harta-negara diakses pada 9 Mei 2020 pukul 21.00

${ }^{9}$ Undang-Undang Nomor 15 Tahun 2006 tentang Badan Pemeriksa Keuangan

${ }^{10}$ Ibid
} 
keuangan negara yang wajib disampaikan kepada BPK;

e. menetapkan standar pemeriksaan keuangan negara setelah konsultasi dengan Pemerintah Pusat/Pemerintah Daerah yang wajib digunakan dalam pemeriksaan pengelolaan dan tanggung jawab keuangan negara;

f. menetapkan kode etik pemeriksaan pengelolaan dan tanggung jawab keuangan negara;

g. menggunakan tenaga ahli dan/atau tenaga pemeriksa di luar BPK yang bekerja untuk dan atas nama BPK;

h. membina jabatan fungsional Pemeriksa;

i. memberi pertimbangan atas Standar Akuntansi Pemerintahan; dan

j. memberi pertimbangan atas rancangan sistem pengendalian intern Pemerintah Pusat/ Pemerintah Daerah sebelum ditetapkan oleh Pemerintah Pusat/Pemerintah Daerah

Kewenangan-kewenangan yang dapat dimiliki oleh BPK ini tidak lepas dari fungsi-fungsi dari BPK itu sendiri. Pertama, BPK memiliki fungsi operasional, yaitu fungsi untuk melaksanakan pemeriksaan terhadap tangggung jawab keuangan negara dan juga pelaksanaan APBN. Kedua, BPK memiliki fungsi yudikatif untuk melakukan peradilan kompatibel terhadap tuntutan perbendaharaan. Ketiga, BPK memiliki fungsi rekomendasi dengan memberikan saran atau pertimbangan kepada Pemerintah apabila dianggap perlu untuk kepentingan negara maupun hal yang berhubungan dengan keuangan negara. ${ }^{[11]}$

Dalam melakukan pemeriksaan, BPK dapat menghubungi aparat pengawasan intern untuk menggunakan hasil pemeriksaan yang telah dilakukan oleh aparat tersebut. ${ }^{[12]}$ Dalam hal meminta keterangan tersebut, BPK dapat melakukan panggilan kepada pihak-pihak yang dibutuhkan. Pemeriksa juga dapat melakukan pengujian serta penilaian atas sistem pengendalian intern pemerintah dengan melakukan pemeriksaan investigative untuk mengungkapkan apabila ada indikasi kerugian keuangan ataupun unsur pidana. ${ }^{[13]}$ Pemeriksaan sebagai bagian krusial dalam pengawasan yang dilakukan oleh BPK dilakukan dengan independen berdasarkan standar pemeriksaan guna mencapai kebenaran, kecermatan, kredibilitas dan keandalan informasi mengenai pengelolaan dan tanggung jawab. ${ }^{[14]}$ Segala kewenangan yang dimiliki oleh BPK beserta batasannya bertujuan untuk mengawasi kinerja Pengelola Keuangan Negara sebagai pihak ketiga sehingga dapat mencapai tujuan bernegara, serta membangun hubungan kepercayaan antara lembaga perwakilan rakyat dengan pemerintah.

\section{B. Mekanisme Pengawasan yang dilakukan oleh BPK terhadap Pengelolaan Keuangan Negara}

Dalam penjelasan umum Undang-Undang Nomor 15 Tahun 2006 tentang Badan Pemeriksa Keuangan menjelaskan bahwa:[15] "Pemeriksaan adalah proses identifikasi masalah, analisis, dan evaluasi yang dilakukan secara independen, obyektif, dan profesional berdasarkan standar pemeriksaan, untuk menilai kebenaran, kecermatan, kredibilitas, dan keandalan informasi mengenai

\footnotetext{
${ }^{11}$ Adrian Sutedi, 2010, Hukum Keuangan Negara, Sinar Grafika, Jakarta, hal. 234.

12 Andini Rahmayanti Pontoh, "Tugas dan Wewenang BPK dalam Pengawasan Pengelolaan Keuangan BUMN/BUMD”, Lex Administratum, Volume 1 Nomor 1, Januari-Maret, 2013, hal. 136

${ }^{13}$ Ibid

14 BPK RI, "Gambaran Umum BPK”, hal. 6, diakses melalui https://www.bpk.go.id/assets/files/storage/2017/12/file_ storage_1512639232.pdf pada 15 Mei 2020

${ }^{15}$ Penjelasan Umum Undang-Undang Nomor 15 Tahun 2006 tentang Badan Pemeriksa Keuangan 
pengelolaan dan tanggung jawab keuangan negara." Pemeriksaan Keuangan Negara atau Audit Keuangan Negara mencakup proses identifikasi masalah, analisis, dan evaluasi yang dilakukan secara independent, objektif, dan profesional berdasarkan standar pemeriksaan BPK untuk menilai kebenaran, kecermatan, kredibilitas, dan keandalan informasi mengenai pengelolaan dan tanggung jawab Keuangan Negara. ${ }^{[16]}$ Proses pemeriksaan keuangan negara ini meliputi seluruh rangkaian kegiatan yang berkaitan dengan objek keuangan negara mulai dari perumusan kebijakan, pengambilan keputusan, sampai pertanggungjawaban laporan hasil pemeriksaan.

Kerja BPK bersifat mandatory, melakukan pemeriksaan keuangan negara kepada seluruh entitas yang menggunakan uang negara. Setelah proses mandatory berjalan, bisa jadi timbul kasus (untuk ditelusuri). Proses mandatory dilakukan dengan tiga hal, audit laporan keuangan, audit kinerja, dan audit dengan tujuan tertentu. Pertengahan semester pertama biasanya BPK disibukan dengan meng-audit laporan keuangan. Terhadap audit laporan keuangan BPK yang mengindikasikan kerugian negara nantinya bisa ditindaklanjuti lagi dengan tujuan tertentu. Adanya kasus ini timbul karena mandatory BPK. Karena tujuan BPK adalah mendorong pemerintah tertib administratif. ${ }^{[17]}$

BPK mempunyai kebebasan dan kemandirian dalam proses yang meliputi tiga tahap pemeriksaan, yaitu perencanaan, pelaksanaan, dan pelaporan hasil pemeriksaan. Kebebasan dalam tahap perencanaan ini mencakup kebebasan untuk menentukan objek yang akan diperiksa, kecuali pemeriksaan yang objeknya telah diatur tersendiri dalam undang-undang, atau pemeriksaan berdasarkan permintaan khusus dari lembaga perwakilan. Dalam perencanaan tugas pemeriksaan, BPK memperhatikan permintaan, saran, dan pendapat lembaga perwakilan yang berupa hasil keputusan rapat paripurna, rapat kerja, dan alat kelengkapan lembaga perwakilan yang disampaikan dalam rapat paripurna DPR untuk dipergunakan sebagai bahan pengawasan. ${ }^{[18]}$ Dalam rangka membahas saran, permintaan, dan pendapat tersebut, BPKatau lembaga perwakilan mengadakan pertemuan untuk melakukan konsultasi. BPK juga mempertimbangkan informasi masyarakat berupa penelitian dan pengembangan, kajian, pendapat dan keterangan organisasi profesi terkait, berita media massa, pengaduan langsung dari masyarakat, juga informasi dari pemerintah termasuk lembaga independen yang dibentuk dalam upaya pemberantasan korupsi, kolusi, dan nepotisme, ${ }^{[19]}$ seperti Komisi Pemberantasan Korupsi (KPK), Komisi Pengawasan Persaingan Usaha (KPPU), dan Pusat Pelaporan dan Analisis Transaksi Keuangan (PPATK).

Dalam menyelenggarakan pemeriksaannya terhadap pengelolaan keuangan dan tanggung jawab keuangan Negara, BPK dapat memanfaatkan hasil pemeriksaan aparatur pengawasan

\footnotetext{
${ }^{16}$ Penjelasan Umum, Undang-Undang Nomor 15 Tahun 2004 Tentang Pemeriksaan Pengelolaan dan Tanggung Jawab Keuangan Negara

${ }_{17}$ Dinda Audriene Muthmainah “Menelisik Cara Kerja BPK dalam Memeriksa Keuangan Negara” diakses melalui https:// www.cnnindonesia.com/ekonomi/20170731084819-84-231374/menelisik-cara-kerja-bpk-dalam-memeriksa-keuangan-negara pada tanggal 16 Mei 2020

${ }^{18}$ Mieke Rayu Raba, "Peran Badan Pemeriksa Keuangan (BPK) Dalam Melakukan Pemeriksaan Terhadap Pengelolaan Keuangan Negara Untuk Mewujudkan Pemerintahan Yang Baik Menurut UU No. 15 Tahun 2006”, Lex Crimen Vol. VI/No. 3/Mei/2017, hal. 156.

${ }_{19}$ Pasal 8 Undang-Undang Republik Indonesia Nomor 15 Tahun 2004 Tentang Pemeriksaan Pengelolaan Dan Tanggung Jawab Keuangan Negara.
} 
intern pemerintah. Laporan hasil pemeriksaan intern pemerintah harus di sampaikan kepada BPK. ${ }^{[20]}$ Laporan hasil pemeriksaan intern pemerintah bertujuan untuk menjadi informasi bagi BPK dalam upaya mengungkap ketidakbenaran dalam pengelolaan keuangan negara yang menimbulkan kerugian terhadap keuangan Negara. ${ }^{[21]}$ BPK juga memiliki kewenangan yang meliputi tiga macam pemeriksaan, ${ }^{[22]}$ sebagaimana diatur dalam BAB XI Pasal 2 hingga Pasal 5 Undang-Undang Nomor 15 Tahun 2004 tentang Pemeriksaan Pengelolaan dan Tanggungjawab Keuangan Negara, kewenangan tersebut ialah sebagai berikut: ${ }^{[23]}$

1. Pemeriksaan keuangan, yaitu pemeriksaan yang dilakukan atas laporan keuangan yang dibuat oleh Kepala Daerah dengan maksud mengevaluasi tingkat kewajaran yang disajikan dalam laporan. Pemeriksaan keuangan diakhir dengan opini atau pendapat BPK tentang kewajaran laporan keuangan Pemerintah Daerah.

2. Pemeriksaan kinerja, yaitu pemeriksaan atas pengelolaan keuangan negara yang terdiriatas pemeriksaan aspek ekonomi, dan efisiensi serta pemeriksaan aspek efektivitas. Pemeriksaan kinerja menghasilkan kesimpulan apakah kegiatan yang dibiayai oleh keuangan daerah telah diselenggarakan secara ekonomis dan efisien serta memenuhi sasarannya secara efektif. Di sinilah kemudian terdapat temuan-temuan BPK yang selanjutnya diberikan rekomendasi penyelesaiannya.

3. Pemeriksaan dengan tujuan tertentu, yaitu pemeriksaan yang tidak termasuk dalam butir 1, dan butir 2. Termasuk dalam pemeriksaan ini adalah pemeriksaan investigatif yang dilakukan atas permintaan aparat penegak hukum."

Laporan yang dilaksanakan oleh akuntan publik diperlukan supaya BPK dapat melakukan evaluasi pemeriksaan yang dilaksanakan. Selain itu, Peraturan Badan Pemeriksa Keuangan Republik Indonesia Nomor 2 Tahun 2016 Tentang Tata Kerja Badan Pemeriksa Keuangan juga menjelaskan bahwa dalam melaksanakan tugas pemeriksaannya BPK dapat menggunakan pemeriksa dan/atau tenaga ahli dariluar BPKyang bekerja untuk dan atas nama BPK. ${ }^{[24]}$ Kemudian, menurut UU No. 15 Tahun 2004, dalam melaksanakan tugas pemeriksaan tersebut, pemeriksa dapat: "a. Meminta dokumen yang wajib disampaikan oleh pejabat atau pihak lain yang berkaitan dengan pelaksanaan pemeriksaan pengelolaan dan tanggung jawab keuangan Negara; $b$. Mengakses semua data yang disimpan di berbagai media, aset, lokasi, dan segala jenis barang atau dokumen dalam penguasaan atau kendali dan entitas yang menjadi objek pemeriksaan atau entitas lain yang dipandang perlu dalam pelaksanaan tugas pemeriksaannya; c. Melakukan penyegelan tempat penyimpanan uang, barang, dan dokumen pengelolaan keuangan Negara; d. Meminta keterangan kepada seseorang; e. Memotret, merekam dan/atau mengambil sampel sebagai alat bantu pemeriksaan."[25]

Dalam pelaksanaan pemeriksaan pengelolaan dan tanggung jawab keuangan negara, BPK melakukan pembahasan atas temuan pemeriksaan dengan objek yang diperiksa sesuai

20 Hendar Ristriawan, "Pengawasan Keuangan Negara dan Pemeriksaan Keuangan Negara" disampaikan dalam Kuliah Umum Fakultas Hukum Universitas Padjadjaran, pada 21 Mei 2020.

${ }^{21}$ Muhammad Djafat Saidi, 2007, Hukum Keuangan Negara, PT Raja Grafindo Persada, Jakarta, hal. 63-65.

${ }^{22}$ Bachrul Amiq, "Pengawasan BPK Dalam Mewujudkan Pengelolaan Keuangan Daerah Yang Bebas Korupsi", Jurnal Jatiswara, 31(2), 2017, hal. 5.

${ }^{23}$ Pasal 2 Undang-Undang Nomor 15 Tahun 2004 Tentang Pemeriksaan Pengelolaan dan Tanggungjawab Keuangan Negara

${ }^{24}$ Pasal 33 Peraturan Badan Pemeriksa Keuangan Republik Indonesia Nomor 2 Tahun 2016 Tentang Tata Kerja Badan Pemeriksa Keuangan

25 Pasal 10 Undang-Undang Nomor 15 Tahun 2004 tentang Pemeriksaan Pengelolaan dan Tanggung Jawab Keuangan Negara 
dengan standar pemeriksaan keuangan negara. Pembahasan ini diperlukan dalam rangka mengkonfirmasi dan mengklarifikasi temuan pemeriksaan BPK tersebut dengan pihak yang diperiksa. Hasil pemeriksaan BPK itu kemudian dijadikan bahan untuk melakukan koreksi dan penyesuaian sehingga laporan keuangan yang telah diperiksa dapat memuat koreksi dimaksud sebelum disampaikan kepada DPR, DPD, dan DPRD sesuai dengan kewenangannya. Tata cara pelaksanaan tugas BPK diatur lebih lanjut di dalam Peraturan BPK. ${ }^{[26]}$

Kemandirian dan kebebasan dari ketergantungan kepada pemerintah dalam hal kelembagaan, pemeriksaan, dan pelaporan sangat diperlukan BPK agar dapat melaksanakan tugas yang diamanatkan oleh UUD 1945. ${ }^{[27]}$ Pasal 6 ayat (1) UU BPK menjelaskan bahwa BPK bertugas memeriksa pengelolaan dan tanggung jawab keuangan negara yang dilakukan oleh Pemerintah Pusat, Pemerintah Daerah, Lembaga Negara lainnya, Bank Indonesia, Badan Usaha Milik Negara, Badan Layanan Umum, Badan Usaha Milik Daerah, dan lembaga atau badan lain yang mengelola keuangan negara. Di samping itu, dalam melaksanakan pemeriksaan pengelolaan dan tanggung jawab keuangan negara tersebut, BPK memiliki tugas melakukan pembahasan atas temuan pemeriksaan dengan objek yang diperiksa sesuai dengan standar pemeriksaan keuangan negara.

\section{Hasil Temuan BPK}

Berikut tujuh temuan pemeriksaan atas sistem pengendalian intern dan kepatuhan yang dilakukan BPK: ${ }^{[28]}$

1. Pelaporan atas kebijakan baru pemerintah, di antaranya penetapan harga jual BBM dan listrik, serta kerja sama pemerintah dengan badan usaha (KPBU) yang menimbulkan dampak terhadap realisasi anggaran, aset, dan kewajiban belum ditetapkan standar akuntasinya.

2. Dasar hukum, metode perhitungan, dan mekanisme penyelesaian kompensasi atas dampak kebijakan penetapan tarif tenaga listrik (TTL) nonsubsidi belum ditetapkan.

3. Pencatatan rekonsiliasi dan monitoring valuasi aset Kontraktor Kontrak Kerja Sama (KKKS) dan perjanjian kerja sama karya (KK) pengusahaan pertambangan batu bara belum memadai.

4. Skema pengalokasian anggaran dan realisasi pengadaan tanah proyek strategis nasional pada pos pembiayaan dan realisasi pembangunan aset konstruksi jalan tol belum didukung dengan standar dan kebijakan akuntansi yang lengkap.

5. Data sumber perhitungan afirmasi dan alokasi formula pada pengalokasian dana desa pada alokasi anggaran 2018 belum andal.

6. Pengalokasian dana alokasi khusus (DAK) fisik tahun anggaran 2018 sebesar Rp 15,51 Triliun belum sepenuhnya sesuai dengan peraturan perundang-undangan dan tidak didukung dengan dokumen sumber yang memadai.

7. Adanya kelemahan pengadilan intern dan ketidakpatuhan dalam penatausahaan dan pencatatan kas setara kas, PNBP, belanja, piutang PNBP, persediaan aset tetap dan utang, terutama pada kementerian/lembaga.

Konstitusi telah mensejajarkan kedudukan BPK sebagai lembaga tinggi negara yang setara dengan Presiden, DPR dan DPD. Oleh karena itu, jelas bahwa BPK merupakan lembaga

${ }^{26}$ Andini Rahmayanti Pontoh, Op. Cit, hal. 137

${ }^{27}$ Beni Kurnia Illahi dan Muhammad Ikhsan Alia, "Pertanggungjawaban Pengelolaan Keuangan Negara Melalui Kerja Sama BPK dan KPK", Volume 3 Nomor 2 - Desember 2017, hal. 43

${ }^{28}$ Dwi Bowo Raharjo, "Ini tujuh Temuan BPK RI Terkait Laporan Pemeriksaan Keuangan” diakses melalui https://www. suara.com/news/2019/05/29/183137/ini-tujuh-temuan-bpk-ri-terkait-laporan-pemeriksaan-keuangan pada 21 Mei 2020 
pengawasan yang bersifat eksternal, dimana secara struktural BPK bukan merupakan bagian dari pemerintah. Demikian pula dengan para auditor BPK yang tidak berada dalam suatu hubungan pekerjaan atasan-bawahan dengan objek yang diperiksa. Dengan demikian lembaga yang dibentuk secara khusus untuk mengawasi keuangan ini (pengawas fungsional), secara logika akan bisa menghasilkan temuan yang lebih objektif. ${ }^{[29]}$

\section{Jenis Pengawasan BPK}

Berdasarkan lingkup kewenangan BPK, secara teoritis kewenangan pengawasan BPK atas pengelolaan keuangan dapat dikelompokkan dalam pengawasan represif, yakni pengawasan atas pelaksanaan dari anggaran atau pengawasan a-posteriori. Pengawasan a-posteriori merupakan pengawasan yang dilakukan sesudah dikeluarkannya keputusan atau ketetapan pemerintah ataupun setelah kegiatan dilakukan. Dalam hal keputusan atau ketetapan pemerintah, maka pengawasan jenis ini dilakukan untuk melihat bagaimana pelaksanaan keputusan atau ketetapan tersebut, apakah dalam pelaksanaannya telah sesuai dengan tujuan atau maksud diterbitkan keputusan atau ketetapan tersebut. Dalam hal kegiatan pemerintah, biasanya dilakukan pada akhir tahun, pengawasan represif ini bermaksud untuk mengetahui apakah suatu kegiatan dan pembiayaan yang telah dilakukan itu telah mengikuti kebijaksanaan dan ketentuan yang telah ditetapkan dan pengawasan ini dilakukan setelah pekerjaan atau kegiatan dilaksanakan. Selain itu, pengawasan represif dapat dikatakan juga sebagai salah satu bentuk pengawasan atas jalannya pemerintahan. ${ }^{[30]}$ Tiga jenis Pemeriksaan BPK, baik pemeriksaan keuangan, pemeriksaan kinerja, maupun pemeriksaan dengan tujuan tertentu merupakan bentuk-bentuk pengawasan terhadap tahapan pelaksanaan pengelolaan keuangan negara.

\section{Tindak Lanjut Hasil Pemeriksaan oleh BPK dalam Melakukan Pengawasan terhadap Pengelolaan Keuangan Negara}

Dalam melakukan pemeriksaan, BPK menemukan beberapa penyimpangan, berupa: Penyimpangan yang mengganggu kewajaran penyajian laporan keuangan; Penyimpangan terhadap kriteria/peraturan yang telah ditetapkan; Penyimpangan yang dapat mengganggu asas kehematan; Penyimpangan yang dapat mengganggu asas efisiensi; dan Penyimpangan yang dapat mengakibatkan tidak tercapaian yang direncanakan. ${ }^{[31]}$ Output yang dihasilkan dari pemeriksaan yang dilakukan oleh BPK tersebut berupa Hasil Akhir, sebagaimana disebutkan dalam Pasal 1 Angka 1 UU No. 15 Tahun 2006 BPK: "Hasil Pemeriksaan adalah hasil akhir dari proses penilaian kebenaran, kepatuhan, kecermatan, kredibilitas, dan keandalan data/informasi mengenai pengelolaan dan tanggung jawab keuangan negara yang dilakukan secara independen, objektif, dan profesional berdasarkan Standar Pemeriksaan,yang dituangkan dalam laporan hasil pemeriksaan sebagai keputusan BPK."

1. Mekanisme Pelaporan Hasil Pemeriksaan BPK

${ }^{29}$ Bachrul Amiq, "Pengawasan BPK Dalam Mewujudkan Pengelolaan Keuangan Daerah Yang Bebas Korupsi", Jurnal Jatiswara, 31(2), 2017, hal. 5.

30 Sujamto, 1986 dalam sari kuliah Amelia Cahyadini, "Pengawasan Sebagai bagian dari penegakan Hukum Administrasi Negara", disampaikan dalam Kuliah Hukum Pengawasan Fakultas Hukum Universitas Padjadjaran, pada 17 Maret 2020.

${ }^{31}$ Ikhwan Fahrojih dalam Mieke Rayu Raba, 2017, "Peran Badan Pemeriksa Keuangan (BPK) dalam Melakukan Pemeriksaan Terhadap Pengelolaan Keuangan Negara untuk Mewujudkan Pemerintahan yang Baik Menurut UU No. 15 Tahun 2006” Jurnal Lex Crimen, Vol. VI/No.3/Mei/2017, hal. 156 
Terhadap hasil pemeriksaan tersebut, Pasal 7 Ayat (1) UU No. 15 Tahun 2006 BPK menyebutkan bahwa: "BPK menyerahkan hasil pemeriksaan atas pengelolaan dan tanggung jawab keuangan negara kepada DPR, DPD, dan DPRD sesuai dengan kewenangannya". Mengenai laporan hasil pemeriksaan atas Laporan Keuangan Pemerintah Pusat (LKPP), BPK menyerahkannya kepada DPR. Pemeriksaan atas LKPP tersebut dilakukan setiap tahun. Di samping itu, BPK juga menyusun laporan hasil pemeriksaan yang dilakukan setiap semester atau disebut juga Ikhtisar Hasil Pemeriksaan Semester (IHPS). ${ }^{[32]}$ Hasil pemeriksaan semester ini juga kemudian menjadi kewenangan pengawasan oleh DPR sebagaimana tercantum dalam Pasal 163 Ayat (3) Peraturan DPR No. 1 Tahun 2014 tentang Tata Tertib DPR RI yang menyebutkan bahwa: "Pengawasan sebagaimana dimaksud dalam Pasal 162 ayat (2) huruf b dapat dilakukan melalui: a. pembahasan laporan keuangan Pemerintah Pusat yang telah diaudit oleh BPK; $b$. hasil pemeriksaan semester BPK; c. tindak lanjut hasil pemeriksaan semester BPK; d. hasil pemeriksaan dengan tujuan tertentu oleh $B P K$; e. hasil pengawasan DPD, dan/atau; $f$. pengaduan masyarakat."

Sebelum hasil pemeriksaan tersebut diserahkan kepada DPR, BPKdilarang mempublikasikan isi hasil pemeriksaan tersebut kepada pihak lain, termasuk kepada pemerintah maupun media massa. Namun, setelah diserahkan kepada DPR, hasil pemeriksaan tersebut dinyatakan terbuka untuk umum sebagaimana diatur dalam Pasal 7 ayat (5) UU No. 15 Tahun 2006 BPK yang mengemukakan bahwa: "Hasil pemeriksaan atas pengelolaan dan tanggung jawab keuangan negara yang telah diserahkan kepada DPR, DPD, dan DPRD dinyatakan terbuka untuk umum." Fungsi dari disebarluaskannya hasil pemeriksaan ini kepada media massa adalah agar masyarakat dapat ikut andil dalam mengawasi kinerja pemerintah dan juga BPK itu sendiri.

2. Pertanggungjawaban Hasil Pemeriksaan BPK

Pasal 8 Ayat (3) UU No. 15 Tahun 2006 BPK menyebutkan bahwa: "Apabila dalam pemeriksaan ditemukan unsur pidana, BPK melaporkan hal tersebut kepada instansi yang berwenang sesuai dengan ketentuan peraturan perundang-undangan paling lama 1 (satu) bulan sejak diketahui adanya unsur pidana tersebut". Instansi yang berwenang dalam hal ini adalah pihak Kepolisian, Kejaksaan, dan Komisi Pemberantasan Korupsi. Laporan ini nantinya akan menjadi bahan awal bagi dasar penyelidikan atau penyidikan oleh pejabat yang berwenang. ${ }^{[33]}$ Selanjutnya Pasal 11 UU No. 15 Tahun 2006 BPK mejelaskan bahwa "BPK dapat memberikan: a. pendapat kepada DPR, DPD, DPRD, Pemerintah Pusat/Pemerintah Daerah, Lembaga Negara Lain, Bank Indonesia, Badan Usaha Milik Negara, Badan Layanan Umum, Badan Usaha Milik Daerah, Yayasan, dan lembaga atau badan lain, yang diperlukan karena sifat pekerjaannya; $b$. pertimbangan atas penyelesaian kerugian negara/daerah yang ditetapkan oleh Pemerintah Pusat/Pemerintah Daerah; dan/atau c. keterangan ahli dalam proses peradilan mengenai kerugian negara/daerah."

Dalam hal pemeriksaan oleh BPK menunjukkan adanya kerugian negara, hal tersebut tidak serta merta dikategorikan sebagai tindak pidana korupsi. Bila BPK menilai kerugian tersebut hanya terjadi karena kelalaian, bukan karena tujuan memperkaya diri sendiri, BPKakan meminta pihak yang bertanggung jawab untuk mengganti kerugian tersebut dengan cara membayar uang yang harus dikembalikan kepada kas negara.

"Pasal 10 UU No. 15 Tahun 2006 BPK:

(1)BPK menilai dan/atau menetapkan jumlah kerugian negara yang diakibatkan oleh perbuatan melawan hukum baik sengaja maupun lalai yang dilakukan oleh bendahara,

\footnotetext{
${ }^{32}$ BPK RI, 2019, Mengenal Lebih Dekat BPK Sebuah Paduan Populer, Biro Humas Dan Luar Negeri BPK RI, hal. 69

${ }^{33}$ BPK RI, Op. Cit, hal. 76
} 
pengelola BUMN/BUMD, dan lembaga atau badan lain yang menyelenggarakan pengelolaan keuangan negara.

(2)Penilaian kerugian keuangan negara dan/atau penetapan pihak yang berkewajiban membayar ganti kerugian sebagaimana dimaksud pada ayat (1) ditetapkan dengan keputusan BPK."

Sebagaimana diatur dalam pasal di atas, jumlah ganti rugi ditetapkan oleh BPK berdasarkan penilaian BPK mengenai jumlah kerugian negara yang diakibatkan oleh kelalaian tersebut. Untuk menjamin pelaksanaan pembayaran ganti rugi tersebut, BPK memiliki kewenangan untuk memantau pelaksanaan ganti rugi sebagaimana ditentukan dalam Pasal 10 Ayat (3) UU No. 15 Tahun 2006 BPK: “Untuk menjamin pelaksanaan pembayaran gantikerugian, BPK berwenang memantau: a. penyelesaian ganti kerugian negara/daerah yang ditetapkan oleh Pemerintah terhadap pegawai negeri bukan bendahara dan pejabat lain; b. pelaksanaan pengenaan ganti kerugian negaral daerah kepada bendahara, pengelola BUMN/BUMD, dan lembaga atau badan lain yang mengelola keuangan negara yang telah ditetapkan oleh BPK; dan c. pelaksanaan pengenaan ganti kerugian negara/daerah yang ditetapkan berdasarkan putusan pengadilan yang telah mempunyai kekuatan hukum tetap". Hasil pemantauan ini kemudian dilaporkan secara tertulis kepada DPR, DPD, dan DPRD. Hasil laporan tersebut akan mempengaruhi opini yang diberikan BPK terhadap pihak yang diperiksanya.

3. Opini BPK

BPK memberikan penilaian berbentuk opini yang terbagi menjadi 4 (empat) kategori opini, yaitu: ${ }^{[34]}$

a. Opini Wajar Tanpa Pengecualian (WTP) atau Unqualified Opinion.

Laporankeuanganyang diperiksa oleh BPKtelah disajikan dengan wajar dan disusun dengan memuaskan tanpa kesalahan. BPK meyakini bahwa berdasarkan buktibukti audit yang dikumpulkan, pemerintah dianggap telah menyelenggarakan prinsip akuntansi yang berlaku umum dengan baik, dan kalaupun ada kesalahan, kesalahannya dianggap tidak material dan tidak berpengaruh signifikan terhadap pengambilan keputusan.

b. Opini Wajar Dengan Pengecualian (WDP) atau Qualified Opinion.

Laporan keuangan yang diperiksa oleh BPK telah disajikan secara wajar, namun terdapat beberapa bagian tertentu yang belum memenuhi standar pengelolaan keuangan. Ada beberapa keadaan yang menyebabkan ditambahkannya paragraf penjelasan. Misalnya, kelemahan sistem pengendalian internal lembaga, ketidakpatuhan terhadap peraturan perundang-undangan, tidak hemat dan efisien.

c. Opini Tidak Wajar (TW) atau Adverse Opinion.

Laporan keuangan yang diperiksa oleh BPK tidak sesuai dengan standar pengelolaan keuangan yang telah ditetapkan dan penyusun laporan keuangan tersebut tidak mau melakukan perbaikan meski sudah ada koreksi yang diajukan oleh auditor dalam proses pemeriksaan. BPK meyakini laporan keuangan tersebut diragukan kebenarannya dan bisa menyesatkan pengguna laporan keuangan tersebut dalam mengambil keputusan.

d. Menolak Memberikan Pendapat atau Tidak Memberikan Pendapat atau Disclaimer Opinion.

Auditor tidak dapat memberikan kesimpulan atau pendapat atas laporan keuangan, hal ini dapat disebabkan oleh berbagai faktor, misalnya karena pihak yang diperiksa membatasi ruang lingkup pemeriksaan.

${ }^{34}$ Ibid, hal. 78-79 
Dengan adanya Opini BPK tersebut, diharapkan pemerintah dapat memperbaiki kinerja pengelolaan dan tanggung jawab terhadap keuangan negara untuk menghindari kesalahan serupa di periode selanjutnya. Peran BPK ini pada dasarnya sangat membantu untuk menanggulangi kerugian negara akibat pengelolaan keuangan oleh lembaga-lembaga negara yang kurang baik. Mengingat sifat pengawasannya yang Eksternal dan Represif, Kemandirian yang dimiliki oleh BPK sebagai lembaga negara yang independent ini menjadi salah satu upaya dalam mengurangi praktik KKN dan membongkar segala bentuk kejahatan terhadap keuangan negara. Kehadiran BPK akan menjadikan setiap pihak yang mengelola keuangan negara sadar, bahwa bila mereka menyalahgunakan anggaran, tindakan itu diketahui dan dibongkar oleh lembaga pemeriksaan yang independen. ${ }^{[35]}$ Adanya Laporan Hasil Pemeriksaan merupakan bentuk pengawasan represif dan pelaksanaan prinsip akuntabilitas bahwa setiap akhir dari kegiatan penyelenggara negara harus dapat dipertanggungjawabkan kepada masyarakat atau rakyat sebagai pemegang kekuasaan tertinggi sesuai dengan peraturan perundang-undangan yang belaku. Pemeriksaan yang dilakukan oleh BPK ini juga berfungsi sebagai pendeteksi kelemahan dalam sistem pengelolaan keuangan negara dan lembaga-lembaga negara.

\section{KESIMPULAN}

BPK lahir sebagai pengawas kinerja pemerintah untuk dilaporkan kepada lembaga perwakilan rakyat sehingga timbul rasa percaya kepada pemerintah. Kewenangan yang dimiliki BPK bersumber dari amanat UUD 1945, dan sejak tahun 2003 telah ada 4 (empat) undangundang yang dijadikan landasan operasional BPK. Bentuk pengawasan yang dilakukan BPK ini adalah pengawasan Represif, dimana pengawasan tersebut dilakukan setelah pekerjaan dilaksanakan dan pengawasan yang dilakukan oleh BPK bersifat Eksternal, dimana pemeriksaan dilakukan oleh lembaga yang berada di luar badan/lembaga yang sedang diperiksa, dan dengan ini objektivitas dari pengawasan yang dilakukan eksternal ini cenderung lebih dapat dipercaya. Hasil pemeriksaan oleh BPK dilaporkan kepada DPR, kemudian kepada pihak lain. Pihak-pihak yang menggunakan hasil pemeriksaan tersebut antara lain: lembaga perwakilan rakyat sebagai bahan pengawasan lembaga perwakilan terhadap pemerintah, terbuka untuk umum sebagai bahan pengawasan masyarakat terhadap pemerintah dan terhadap BPK, aparat yang berwenang apabila terdapat indikasi tindak pidana sebagai dasar penyidikan, dan pemerintah sebagai bahan perbaikan pengelolaan dan tanggung jawab keuangan negara. Dalam hal ditemukan indikasi tindak pidana, BPK bertugas melaporkan unsur pidana yang ditemukan kepada Aparat Penegak Hukum dan kemudian memantau pelaksanaan tindak lanjut hasil pemeriksaan yang dilakukan oleh pejabat dari entitas yang diperiksa.

\section{DAFTAR PUSTAKA}

\section{A. Buku}

${ }^{35}$ Suhendra, 2015, Konsep Kerugian Negara, (Malang: PT Setera Press), Hal. 228-229 
BPK RI, 2019, Mengenal Lebih Dekat BPK Sebuah Paduan Populer, Biro Humas Dan Luar Negeri BPK RI

Saidi, Muhammad Djafat, 2007, Hukum Keuangan Negara, PT Raja Grafindo Persada, Jakarta.

Suhendra, 2015, Konsep Kerugian Negara, PT Setera Press, Malang.

Sutedi, Adrian, 2010, Hukum Keuangan Negara, Sinar Grafika, Jakarta.

\section{B. Peraturan Perundang-Undangan}

Pemerintah Indonesia, Undang-Undang Dasar Republik Indonesia Tahun 1945.

Pemerintah Indonesia, Undang-Undang Nomor 17 Tahun 2003 tentang Keuangan Negara, Lembaran Negara Republik Indonesia Tahun 2003 Nomor 47, Tambahan Lembaran Negara Republik Indonesia Nomor 4286. Sekretariat Negara. Jakarta.

Pemerintah Indonesia, Undang-Undang Nomor 1 Tahun 2004 tentang Perbendaharaan, Lembaran Negara Republik Indonesia Tahun 2004 Nomor 5, Tambahan Lembaran Negara Republik Indonesia Nomor 4355. Sekretariat Negara. Jakarta.

Pemerintah Indonesia, Undang-Undang Nomor 15 Tahun 2004 tentang Pemeriksaan Pengelolaan dan Tanggung Jawab Keuangan Negara, Lembaran Negara Republik Indonesia Tahun 2004 Nomor 66, Tambahan Lembaran Negara Republik Indonesia Nomor 4400. Sekretariat Negara. Jakarta.

Pemerintah Indonesia, Undang-Undang Nomor 15 Tahun 2006 tentang Badan Pemeriksa Keuangan, Lembaran Negara Republik Indonesia Tahun 2006 Nomor 85, Tambahan Lembaran Negara Republik Indonesia Tahun 2006 Nomor 4654, Sekretariat Negara. Jakarta.

\section{Artikel / Jurnal}

Amiq, Bachrul "Pengawasan BPK dalam Mewujudkan Pengelolaan Keuangan Daerah Yang Bebas Korupsi”, Jurnal Hukum Jatiswara, Volume 31 No. 2 p. 249-263, Oktober, 2017.

Illahi, Beni Kurnia, Muhammad Ikhsan Alia, "Pertanggungjawaban Pengelolaan Keuangan Negara Melalui Kerja Sama BPK dan KPK”, Volume 3 Nomor 2, Desember 2017.

Pontoh, Andini Rahmayanti, "Tugas dan Wewenang BPK dalam Pengawasan Pengelolaan Keuangan BUMN/BUMD”, Lex Administratum, Volume 1 Nomor 1, Januari-Maret, 2013.

Raba, Mieke Rayu, 2017, "Peran Badan Pemeriksa Keuangan (BPK) dalam Melakukan Pemeriksaan Terhadap Pengelolaan Keuangan Negara untuk Mewujudkan Pemerintahan yang Baik Menurut UU No. 15 Tahun 2006", Jurnal Lex Crimen, Vol. VI/No.3/Mei/2017.

Rosyadi, Muhammad Imron Rosyadi, "Wewenang Badan Pemeriksa Keuangan dan Badan Pengawasan Keuangan dan Pembangunan Dalam Menilai Kerugian Keuangan Negara", Mimbar Keadilan, Jurnal Ilmu Hukum, Januari-Juni 2016.

\section{Internet}

BPK RI, https://www.bpk.go.id/id

Muthmainah, Dinda Audriene "Menelisik Cara Kerja BPK dalam Memeriksa Keuangan Negara” https://www.cnnindonesia.com/ekonomi/20170731084819-84-231374/menelisik-cara-kerja-bpkdalam-memeriksa-keuangan-negara diakses pada tanggal 16 Mei 2020

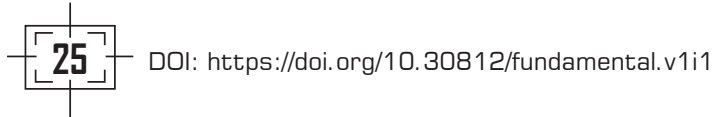


Nawang Xalma Kaldera, Muthi Aulia, Hani Adila Faza| Peran BPK Sebagai Lembaga Pengawas

Raharjo, Dwi Bowo "Ini tujuh Temuan BPK RI Terkait Laporan Pemeriksaan Keuangan" https:// www.suara.com/news/2019/05/29/183137/ini-tujuh-temuan-bpk-ri-terkait-laporanpemeriksaan-keuangan diakses pada 21 Mei 2020 